\title{
THE ROLE OF CITY BYPASSES IN LIMITING TRANSPORT CONGESTION ON THE EXAMPLE OF STAROGARD GDAŃSKI
}

\begin{abstract}
The problem of congestion is one of the key issues faced by cities. There are many ways to improve the functioning of the city's road infrastructure, enabling reduction of the congestion level. The proper level of transport infrastructure development is indispensable for the proper functioning of transport, which determines the effective transport service of residents, and thus improves the broadly understood quality of life.

The article focuses on the effects possible to achieve thanks to the implementation of investments in road infrastructure with particular emphasis on city bypasses. The example of Starogard Gdanski presents the problem of eliminating transit traffic from city centers through the construction of a bypass. The article discusses the results of the experiment carried out to estimate the benefits of the construction of the Starogard Gdański bypass. As part of the experiment, the travel time and fuel consumption were measured during the passage of a passenger car on the route from the planned initial node to the final node of the future bypass. The obtained results were referred to the study of traffic density within DK 22 carried out by GDDKiA Branch in Gdańsk and traffic intensity studies on the intake roads to the city carried out by the Transprojekt Gdansk design company, which allowed to calculate the level of fuel savings, time and reduction of $\mathrm{CO}_{2}$ emissions to the atmosphere, thanks to transfer of transit traffic outside the city limits.
\end{abstract}

Keywords: congestion, transport, city, bypass, investments in transport infrastructure

JEL: R40, R41, R49 


\section{Introduction}

One of the key areas of interest of the European Union is the development and functioning of transport. Due to the growing degradation of the natural environment resulting from the activities of manufacturing enterprises, including transport of the goods produced by them, it is necessary to intensify activities related to environmental protection. In connection with the above, European Union member countries, including Poland, are paying more and more attention to the issue of transport in cities, with particular emphasis on reducing emissions of harmful substances.

Socio-economic development of cities requires adaptation of transport infrastructure to growing needs. The mobility of people and the possibility of getting to cities from more and more distant areas or from those that were previously not possible is increasing. The developed, high-quality transport infrastructure also facilitates the transport of goods. Intensification of this type of activity causes the increase of the number of vehicles passing through cities, and thus the intensification of congestion.

Cities play a very important role in the development of countries and regions, but they encounter barriers related to broadly understood transport, which sometimes even inhibit or significantly slow down their development. Difficulties in transport in Polish cities are the subject of many social, local government and political discussions and are reflected in documents such as, for example, development strategies of cities. The occurrence of congestion is also characteristic for small and medium-sized towns, such as Starogard Gdański. The town is struggling with various transport problems, but especially with the phenomenon of congestion. The most appropriate solution from an economic and social point of view seems to be the construction of a city bypass. For this reason, the article will present the results of the study and the benefits that would result from the implementation of this project.

\section{Methodology and theory}

\subsection{The effects of transport infrastructure development - a review of literature}

Properly developed transport infrastructure and a well-functioning market for broadly understood transport services can be identified as one of the most important features of the economic system that condition transport accessibility. A given region or city can be considered more accessible, the more it is possible to safely, cheaply and, as far as possible, reach the attractive places from the traveler's point of view.

In the literature on the subject, many definitions of the concept of transport infrastructure can be found. Piskozub (1982) defines the infrastructure as follows: "infrastructure is (...) man-made, permanently located, linear and point public facilities, which form the basis of socio-economic life, due to their functions of transporting people and freight (transport), messages (communication), 
electricity (energy) and water (water management)". On this basis, it can be said that the infrastructure consists of construction objects, thanks to which it is possible to transport people and freight. According to Neider (2008), transport infrastructure is constituted by devices and permanent objects necessary for transporting freight. Whereas Gołembska (2010) defines transport infrastructure as points and places used by means of transport during traffic and stopovers, which includes roads and necessary equipment for infrastructure and transport points, such as seaports or airports.

Basing on the literature, three main approaches to studying the relation between investments in transport infrastructure and the development of a given region can be distinguished. Cost-Benefit Analysis (CBA) is currently the most common of the three possible approaches. It is a microeconomic analytical approach and it focuses on improving the productivity of individual enterprises, thanks to investments in transport infrastructure, Lakshmanan (2011). Aschauer (1989) was a precursor of economic modeling, the aim of which was to find solutions to problems with the limited scope and partial nature of CBA research. His actions were aimed at recognizing the wider economic benefits of investment in transport infrastructure. This approach was to take into account general production effects as an additional factor.

Another research stream includes Computable General Equilibrium models (CGE). They were used, among others, by Haddad and Hewings (2005), Haddad et al. (2011), Sakamoto (2012), or Elshahavan, Haddad and Lahr (2016). The latter used this tool to provide a macroeconomic assessment of the planned corridor's impact on the development of Egypt's national and regional economy. They point out that at the same time when all regions improve their transport accessibility measured by travel time, the impact on the rate of regional growth measured by GDP varies. The greatest effect, both in the long and short term, occurred in the regions where the greatest improvement in transport accessibility was noted, but also in some areas, GDP grew at a slower pace compared to others, although the planned investments improved accessibility.

There are many different approaches in the literature regarding the effects obtained from investments in infrastructure and their relation with economic development. Bröcker and Rietveld (2009) indicate that there is no consensus on applications based on studies analyzing the overall infrastructure production effects. However, Vickerman (2008) states that the overall impact of investments in transport infrastructure depends both on its nature and the accompanying circumstances.

From an economic point of view, accessibility is connected with gaining access to markets for both companies and households, e.g. Vickerman (2008). According to this approach, he indicates that improving one link can improve the accessibility of other destinations, without new infrastructural investments there. In this way, the overall increase in the level of availability may be influenced. The significance of spill-over effects is also confirmed by Cantos, Gumbau-Albert and Maudos (2005), Álvarez-Ayuso and Delgado-Rodriguez (2012) or Álvarez-Ayuso et al. (2016) in the case of Spain. A change in the accessibility and hence transport costs, may lead to a significant transfer of economic activity, because a decrease in transport costs 
may favor the agglomeration process. After the emergence of agglomeration, further investments in public infrastructure may strengthen grouping, e.g. Vickerman, Spiekermann and Wegener (1999), Vickerman (2008).

Due to changes in the labor market by reducing travel time, the overall level of productivity can be improved. Employees who could save time travelling to and from the workplace would be more likely to work longer. The enlarged labor market enables employees to look for more productive jobs in the agglomeration due to the possibility of obtaining additional benefits, Venables (2007). The positive impact of better availability on productivity can also be expected in companies. Bąk and Ważna (2014), draw attention to the importance of saving time for the economic effect achieved. They state that since the economic value of time is considered a significant part of transport costs, the possibility of obtaining savings resulting from its shortening should become one of the main arguments deciding on the implementation of transport infrastructural investments and other measures to improve the transport process.

The development of transport infrastructure can also improve the overall reliability of transport Rietveld (1994). In addition, investment in transport infrastructure that improves interregional or international accessibility can further improve local productivity through possible import of knowledge, Karlsson, Grasjo and Andersson (2006). However, it should be noted that for regions with high-quality transport infrastructure, further public investment alone is unlikely to lead to increased efficiency, Banister and Berechman (2001).

The literature also contains publications of research results verifying the impact of improving accessibility to regional development. In the United States, for example, the research was run by Islam (2003) and Lein and Day (2008), who showed positive effects on local employment and urban expansion thanks to the implementation of the Appalachian motorway development program. However, they are specific due to the geographical limitation of the 10-kilometer buffer corridor around motorways. In Europe, Linneker and Spence (1996) assessed the impact of the M25 motorway construction around London on employment growth in the region. They noted that, on the one hand, the increased accessibility of the area could help local companies expand their market and increase employment in an area with better accessibility. On the other hand, it can facilitate the expansion of stronger companies outside the area, because they will have easier access where accessibility has been improved and, as a result, it may increase employment in regions other than those where certain effects were expected. Levkovich, Rouwendal and van Marwijk (2016), studied the impact of improved accessibility on housing prices in the Netherlands. In order to do it, they used two sections of motorways in the Netherlands. The results obtained indicate that the overall effects are positive, regardless of the increase of some of the negative effects, such as pollution, noise or traffic. Ribeiro, Antunes and Paez (2010) verified the impact of investments in transport infrastructure on population growth in Portugal. They found that in some cases changes in accessibility, due to shorter travel times, contributed to increased willingness to settle in regions with better accessibility.

In the majority of cases studied, positive effects of investments in transport infrastructure were pointed out for example by improving the accessibility of individual 
regions, and thus increasing their attractiveness. The results are similar in terms of the impact of investments in transport infrastructure on population growth or company location decisions. All of the above were based on different conceptual approaches, but still showed similar effects.

\subsection{The significance and scope of the planned investment in Starogard Gdański}

In Starogard Gdański for many years there is a lively discussion about actions aimed at getting rid of traffic jams in the town. All the existing authorities stated that the only reasonable and effective solution to the problem of congestion is the construction of the town bypass. It is a project that exceeds the town's budget, which is why it is necessary to involve state institutions in the form of the Ministry of Infrastructure and the General Directorate of National Roads and Motorways (GDDKiA). Therefore, it is necessary to demonstrate the benefits of this investment, which should speed up the decision-making process.

The literature review shows that the lower the level of infrastructure development in a region and the more burdensome bottlenecks due to infrastructure shortages and its services, the more likely it is that relatively few positive investments can result in relatively quick and clear positive consequences in terms of infrastructure improving the efficiency of management and private sector activity. However, the higher the overall level of development of a given region, as well as the level of infrastructure equipment, the harder to expect spectacular and at the same time visible in the short term positive consequences of new infrastructure projects. For this reason, among other things, the development of infrastructure should not be considered in terms of short-term and immediate effects. Significant postponement of the effects of infrastructure development and problems with obtaining a clear answer to the question which of the observed changes in economic activity in a given area can be attributed to the development of infrastructure area source of difficulties in conducting the efficiency analysis of infrastructure projects.

One of the undeniable benefits of the construction of the bypass in Starogard Gdański is that the road constructed due to its location would become part of the European road network, which in turn is part of the government's policy in this respect (National Road Construction Program 2014-2023 with a view to 2025). In this way, it would contribute to satisfying not only domestic transport needs, but also international transport from west to east and indirectly from south to north. The need to build motorways and expressways, and this is to be designed by the Starogard Gdański bypass, is the result of an increase in the number of cars in Poland caused by the development of motorization and the takeover of goods transported previously by rail- by road transport.

It is obvious that every economic activity, especially road building, affects the natural environment. However, any investment in this area apart from negative effects brings a number of benefits including, Kaczyńska and Korycińska (2014):

- saving in fuel consumption resulting from a much smoother ride at a constant speed without unnecessary acceleration and braking; 
- reducing emissions of toxic exhaust components to the atmosphere (mainly $\left.\mathrm{CO}_{2}\right)$;

- shortening travel time by increasing its average speed;

- increasing safety by reducing the number of road accidents as a result of separating traffic lanes in one direction, as well as applying solutions in the form of collision-free crossroads;

- reducing noise reaching built-up areas;

- relieving built-up areas from transit traffic;

- reducing the mechanical wear of such units as: clutch, brakes, gearbox, suspension components, steering, etc. due to the much lower frequency of using these mechanisms, as well as fewer maneuvers in driving a car.

The benefits mentioned above are important but not the only areas of positive effects of the construction of the Starogard Gdański bypass. The implementation of such a large investment will also have a positive impact on the local labor market and, consequently, economic recovery in the whole region. The implementation of road investments requires the involvement of specialists in many areas such as: road construction, bridges, tunnels, flyovers, petrol stations, service stations and other engineering buildings, energy networks, communications, transport, mining and processing industries, and even archaeological works, works at planning, designing, construction supervision, geodetic, legal, etc.

However, like any investment of this type apart from indisputable benefits, it has negative effects, mainly in the area of broadly understood ecology and environmental protection. These include, Kaczyńska and Korycińska (2014):

- loss of agricultural land;

- interference in the natural environment, posing a threat to the animal world;

- interference in the relief of the site in connection with the construction of engineering structures;

- cutting out forests on the areas through which the road runs;

- abandoning cattle grazing in areas adjacent to the road;

- the need to abandon the cultivation of vegetables, shrubs, fruit trees intended for human consumption and many forage crops intended for fodder, due to the contamination of air and soil by fumes.

Bearing the above in mind, the decision to build a bypass should be preceded by a thorough analysis, so that the negative ecological and social consequences are as small as possible, because as practice indicates, it is impossible to avoid them completely, Szafranko (2014). The development of road infrastructure, including the construction of the bypass, requires specific actions so that the investment will involve the least possible ecological effects. The application of the principles of sustainable development seems particularly useful in this respect.

The planned investment is to be located in the Pomeranian Voivodeship, within the Starogard district, in the area of the Starogard Gdański municipal commune and the Starogard Gdański rural commune. The concept assumes a construction of a modern main road of accelerated traffic connected with the existing communication system through designed nodes. The project covers a section of approximately $316 \mathrm{~km}$ to $326 \mathrm{~km}$ of national road No. 22 running from Grzechotki (the eastern border of the state - Kaliningrad Oblast), to Kostrzyn nad Odrą (the western border 
of the state - Germany). In the present state within Starogard Gdański, this road is of an urban character, which is connected with difficulties in traffic on other urban roads intersecting with DK No. 22. The undertaking is aimed at (Transprojekt Gdańsk; STEŚ, 2015):

- increasing the efficiency of the existing road system, and especially passing through the town by transferring transit traffic from DK No. 22 to the bypass;

- improvement of driving comfort and traffic safety;

- reducing the onerousness of transit traffic, especially of heavy vehicles in the center of Starogard Gdański;

- reduction of fuel consumption;

- reduction of noise and exhaust levels in the city center;

- increased interest in new investments in the area of the bypass.

The planned investment will consist in the construction of a new section of DK No. 22 along the new route, which together with the accompanying infrastructure will constitute the Starogard Gdański bypass, approximately $16 \mathrm{~km}$ long.

\section{Results}

\subsection{Research results - benefits from the construction of the Starogard Gdański bypass}

The research carried out by the author was aimed at estimating the benefits from the construction of the Starogard Gdański bypass consisting in shortening the travel time through the town, reducing fuel consumption and $\mathrm{CO}_{2}$ emissions resulting from moving out of transit traffic from the town. To determine what part of the transit crossings were used, the DK 22 traffic intensity tests were carried out by GDDKiA Branch in Gdańsk and the study of traffic intensity on the intake roads to the city carried out by the Transprojekt Gdańsk design company. In order to carry out the relevant analyzes, the design company designated four measuring points (Figure 1):

- PKT-1 within DK 22 on Adama Mickiewicza Street in the area of the crossroads with Starogardzka Street (near the Stud Farm - Riding Club);

- PKT-2 within DK 22 on Zblewska Street towards the west;

- PKT-3 within DW 222 on Gdańska Street towards north;

- PKT-4 within DW 222 on Pelplińska Street.

Currently, the main transit direction for the Starogard Gdański area is the relation: DK22 (PKT-1) - DK22 (PKT-2) servicing the route within DK22 Elbląg-Chojnice, where during the measurement period the share of transit was within 36-40\% (Table 1).

In the area of Starogard Gdański, similarly to other measurement cross-sections in the territory of Poland in the national roads, the dominating traffic is, however, local and regional traffic with the surrounding counties and the Tri-City area. A significant impact on the traffic system in the area of Starogard Gdański is probably also the commissioning of the A1 motorway, which took over a significant part of the distant traffic in the region. 


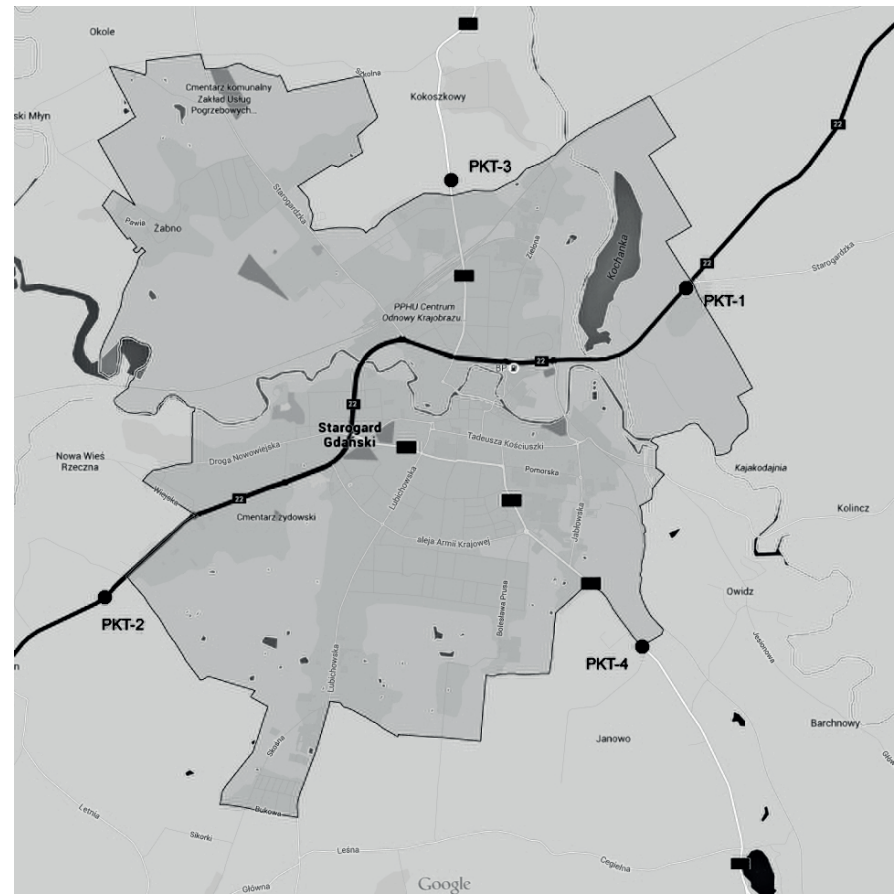

Figure 1. Location of measuring points on entry roads to Starogard Gdański Source: (Transprojekt Gdańsk; STES - measurements of transit traffic flow, 2015)

Table 1. Transit share in the total traffic in cordon points for cordon measurement period 7:15 a.m.-7:15 p.m. in real vehicles (excluding bicycles, motorcycles, farm tractors, excavators)

\begin{tabular}{|c|c|c|c|c|c|c|c|c|c|}
\hline \multirow[b]{2}{*}{ Point } & \multirow{2}{*}{$\begin{array}{l}\text { Number } \\
\text { of vehi- } \\
\text { cles } \\
\text { on the } \\
\text { entry }\end{array}$} & \multicolumn{2}{|c|}{ Transit } & \multirow{2}{*}{$\begin{array}{c}\text { Num- } \\
\text { ber } \\
\text { of vehi- } \\
\text { cles } \\
\text { on the } \\
\text { exit }\end{array}$} & \multicolumn{2}{|c|}{ Transit } & \multirow{2}{*}{$\begin{array}{c}\text { Total } \\
\text { number } \\
\text { of vehi- } \\
\text { cles }\end{array}$} & \multicolumn{2}{|c|}{ Transit } \\
\hline & & $\begin{array}{c}\text { Num- } \\
\text { ber of } \\
\text { vehicles }\end{array}$ & $\begin{array}{c}\text { Share } \\
(\%)\end{array}$ & & $\begin{array}{c}\text { Num- } \\
\text { ber of } \\
\text { vehicles }\end{array}$ & $\begin{array}{c}\text { Share } \\
(\%)\end{array}$ & & $\begin{array}{c}\text { Num- } \\
\text { ber of } \\
\text { vehicles }\end{array}$ & $\begin{array}{l}\text { Share } \\
(\%)\end{array}$ \\
\hline $\begin{array}{l}\text { P-1 Mickiewicza } \\
\text { [DK 22] }\end{array}$ & 5041 & 2038 & $40.4 \%$ & 4754 & 1842 & $38.7 \%$ & 9795 & 3880 & $39.6 \%$ \\
\hline $\begin{array}{l}\text { P-2 Zblewska } \\
\text { [DK 22] }\end{array}$ & 5611 & 1984 & $35.4 \%$ & 5692 & 2108 & $37.0 \%$ & 11,303 & 4092 & $36.2 \%$ \\
\hline $\begin{array}{l}\text { P-3 Gdańska } \\
{[\text { DW 222] }}\end{array}$ & 3239 & 1000 & $30.9 \%$ & 3110 & 1031 & $33.2 \%$ & 6349 & 2031 & $32.0 \%$ \\
\hline $\begin{array}{l}\text { P-4 Pelplińska } \\
\text { [DW 222] }\end{array}$ & 3841 & 870 & $22.7 \%$ & 3826 & 911 & $23.8 \%$ & 7667 & 1781 & $23.2 \%$ \\
\hline
\end{tabular}

Source: (own elaboration based on Transprojekt Gdańsk data; STEŚ - measurements of transit traffic flow, 2015)

The rest of the study consisted of the experiment carried out by the author. As part of the experiment, car journeys with a diesel engine were made on the route from the planned initial node to the final node of the future bypass. During journeys 
at various times, and hence at different traffic, travel time and fuel consumption were measured. The research was being carried out from $11^{\text {th }}$ March 2019 to $17^{\text {th }}$ March 2019, with favorable weather conditions.

The observations were grouped due to the day of the week and the time period. Due to the day of the week, one group includes journeys on working days from Monday to Friday, while in the second group - journeys on Saturday and Sunday. Both the first and the second group were divided into five hourly intervals. Data were also grouped due to the direction of travel - separately from east to west and from west to east. This division was used due to noticeable differences in fuel consumption measurements that appear to be caused by the terrain through which DK 22 runs within the town boundaries. The travel time was measured for separate groups. On the basis of the collected data, the costs of travel and $\mathrm{CO}_{2}$ emissions to the atmosphere were calculated. The obtained results are presented in tabular form (Table 2).

The passage of the test section under favorable road conditions, while maintaining the maximum permitted speed and without handicaps in traffic, is about 12 minutes. The collected data show that the travel times range from 12 to almost 22 minutes. This is a significant difference resulting from the fact that the highest volume of traffic falls between 10 a.m. and 6 p.m. from Monday to Friday, when there is the most intense traffic in the town and transit. It seems that saving 10 minutes to cover a 10 $\mathrm{km}$ section of the route is a significant value for most road users. It should also be noted that this has an impact on the amount of fuel consumed. The collected data indicate that it ranges from 0.66 litres driving towards the west between 2 p.m.- 6 p.m., up to 0.45 litres moving towards the east between 10 p.m.- 6 a.m.

With the data on fuel consumption, the cost of travel and the amount of $\mathrm{CO}_{2}$ emissions to the atmosphere were calculated. Calculations on $\mathrm{CO}_{2}$ emissions were made based on data from the Department of Energy. It states that the consumption of one litre of fuel by a motor vehicle is an average emission of $2.35 \mathrm{~kg}$ of $\mathrm{CO}_{2}$ (U.S. Energy Information Administration, 2017). However, it should be remembered that $\mathrm{CO}_{2}$ emissions from car exhausts are only a part of the $\mathrm{CO}_{2}$ emitted to the atmosphere, because to produce one litre of fuel first oil is extracted, then it is transported to the refinery where it is processed, and finally transported in the form of fuel for gas stations, which also involves additional $\mathrm{CO}_{2}$ emissions. Thus, in fact, burning 1 litre of fuel is associated with even more $\mathrm{CO}_{2}$ emissions to the atmosphere. Taking the above into account and calculating the average fuel consumption from the collected data, the amount of fuel and $\mathrm{CO}_{2}$ emissions for all vehicles passing through Starogard Gdański can be calculated (Table 3 and 4). 
Table 2. Results of the study of time and cost of travel and $\mathrm{CO}_{2}$ emissions

\begin{tabular}{|c|c|c|c|c|c|}
\hline \multicolumn{6}{|c|}{ MONDAY-FRIDAY } \\
\hline \multicolumn{6}{|c|}{ Towards the west } \\
\hline Parameter & $\begin{array}{l}6 \text { a.m.- } \\
10 \text { a.m. }\end{array}$ & $\begin{array}{l}10 \text { a.m.- } \\
2 \text { p.m. }\end{array}$ & $\begin{array}{l}2 \text { p.m.- } \\
6 \text { p.m. }\end{array}$ & $\begin{array}{l}6 \text { p.m.- } \\
10 \text { p.m. }\end{array}$ & $\begin{array}{l}10 \text { p.m.- } \\
6 \text { a.m. }\end{array}$ \\
\hline Travel time (minutes) & 18.00 & 17.60 & 22.20 & 17.80 & 13.00 \\
\hline $\begin{array}{l}\text { Average fuel } \\
\text { consumption (in litres) }\end{array}$ & 0.57 & 0.59 & 0.66 & 0.56 & 0.53 \\
\hline Travel cost & 3.00 & 3.12 & 3.44 & 2.95 & 2.78 \\
\hline $\mathrm{CO}_{2}$ emission (per travel) & 1.34 & 1.40 & 1.54 & 1.32 & 1.25 \\
\hline Total $\mathrm{CO}_{2}$ emission & 2.69 & 2.79 & 3.08 & 2.64 & 2.49 \\
\hline \multicolumn{6}{|c|}{ Towards the east } \\
\hline Parameter & $\begin{array}{l}6 \text { a.m.- } \\
10 \text { a.m. }\end{array}$ & $\begin{array}{l}10 \text { a.m.- } \\
2 \text { p.m. }\end{array}$ & $\begin{array}{l}2 \text { p.m.- } \\
6 \text { p.m. }\end{array}$ & $\begin{array}{l}6 \text { p.m.- } \\
10 \text { p.m. }\end{array}$ & $\begin{array}{l}10 \text { p.m.- } \\
6 \text { a.m. }\end{array}$ \\
\hline Travel time (minutes) & 16.20 & 16.80 & 21.80 & 17.00 & 12.00 \\
\hline $\begin{array}{l}\text { Average fuel } \\
\text { consumption (in litres) }\end{array}$ & 0.49 & 0.52 & 0.61 & 0.48 & 0.45 \\
\hline Travel cost & 2.55 & 2.74 & 3.22 & 2.52 & 2.37 \\
\hline $\mathrm{CO}_{2}$ emission (per travel) & 1.14 & 1.23 & 1.44 & 1.13 & 1.06 \\
\hline Total $\mathrm{CO}_{2}$ emission & 2.28 & 2.45 & 2.89 & 2.26 & 2.12 \\
\hline \multicolumn{6}{|c|}{ SATURDAY-SUNDAY } \\
\hline \multicolumn{6}{|c|}{ Towards the west } \\
\hline Parameter & $\begin{array}{l}6 \text { a.m.- } \\
10 \text { a.m. }\end{array}$ & $\begin{array}{l}10 \text { a.m.- } \\
2 \text { p.m. }\end{array}$ & $\begin{array}{l}2 \text { p.m.- } \\
6 \text { p.m. }\end{array}$ & $\begin{array}{l}6 \text { p.m.- } \\
10 \text { p.m. }\end{array}$ & $\begin{array}{l}10 \text { p.m.- } \\
6 \text { a.m. }\end{array}$ \\
\hline Travel time (minutes) & 13.75 & 16.50 & 18.00 & 15.00 & 13.00 \\
\hline $\begin{array}{l}\text { Average fuel } \\
\text { consumption (in litres) }\end{array}$ & 0.54 & 0.58 & 0.59 & 0.56 & 0.53 \\
\hline Travel cost & 2.81 & 3.05 & 3.10 & 2.91 & 2.78 \\
\hline $\mathrm{CO}_{2}$ emission (per travel) & 1.26 & 1.36 & 1.39 & 1.30 & 1.25 \\
\hline Total $\mathrm{CO}_{2}$ emission & 2.51 & 2.73 & 2.77 & 2.61 & 2.49 \\
\hline \multicolumn{6}{|c|}{ Towards the east } \\
\hline Parameter & $\begin{array}{l}6 \text { a.m.- } \\
10 \text { a.m. }\end{array}$ & $\begin{array}{l}10 \text { a.m.- } \\
2 \text { p.m. }\end{array}$ & $\begin{array}{l}2 \text { p.m.- } \\
6 \text { p.m. }\end{array}$ & $\begin{array}{l}6 \text { p.m.- } \\
10 \text { p.m. }\end{array}$ & $\begin{array}{l}10 \text { p.m.- } \\
6 \text { a.m. }\end{array}$ \\
\hline Travel time (minutes) & 13.50 & 16.00 & 16.00 & 16.00 & 12.00 \\
\hline $\begin{array}{l}\text { Average fuel } \\
\text { consumption (in litres) }\end{array}$ & 0.49 & 0.51 & 0.54 & 0.51 & 0.45 \\
\hline Travel cost & 2.55 & 2.68 & 2.81 & 2.68 & 2.36 \\
\hline $\mathrm{CO}_{2}$ emission (per travel) & 1.14 & 1.20 & 1.26 & 1.20 & 1.06 \\
\hline Total $\mathrm{CO}_{2}$ emission & 2.28 & 2.40 & 2.51 & 2.40 & 2.12 \\
\hline
\end{tabular}

Source: (own elaboration) 
Table 3. Fuel consumption and $\mathrm{CO}_{2}$ emissions under current road conditions (Monday- Friday)

\begin{tabular}{|l|c|c|}
\hline \multicolumn{1}{|c|}{ Parameter } & $\begin{array}{c}\text { Fuel consumption } \\
\text { (litres) }\end{array}$ & $\begin{array}{c}\text { Emission of } \mathrm{CO}_{2} \\
\text { (kilograms) }\end{array}$ \\
\hline City traffic (13,126 vehicles) & $7,363.70$ & $17,304.70$ \\
\hline Transit traffic (7,972 vehicles) & $4,472.30$ & $10,509.90$ \\
\hline Total traffic (21,098 vehicles) & $11,836.00$ & $27,814.60$ \\
\hline Average consumption currently (0.561 litres) \\
\hline Average consumption without transit (0.514 litres) \\
\hline Difference in average combustion (0.047 litres)
\end{tabular}

Source: (own elaboration)

Table 4. Fuel consumption and $\mathrm{CO}_{2}$ emissions under current road conditions (Saturday-Sunday)

\begin{tabular}{|l|c|c|}
\hline \multicolumn{1}{|c|}{ Parameter } & $\begin{array}{c}\text { Fuel consumption } \\
\text { (litres) }\end{array}$ & $\begin{array}{c}\text { Emission of } \mathrm{CO}_{2} \\
\text { (kilograms) }\end{array}$ \\
\hline City traffic (13,126 vehicles) & 7061.79 & $16,595.21$ \\
\hline Transit traffic (7,972 vehicles) & 4288.94 & $10,079.01$ \\
\hline Total traffic (21,098 vehicles) & $11,350.72$ & $26,674.19$ \\
\hline Average consumption currently (0.538 litres) \\
\hline Average consumption without transit (0.511 litres) \\
\hline Difference in average combustion (0.027 litres)
\end{tabular}

Source: (own elaboration)

The above results show what amounts of fuel are consumed, and thus how much $\mathrm{CO}_{2}$ and other harmful compounds are released into the atmosphere. It should also be remembered that the above calculations were made assuming the average combustion of a passenger car from the study. However, it is known that a significant part of the total number of vehicles driving through Starogard Gdański are delivery vehicles, trucks and buses that consume even more fuel and thus emit more $\mathrm{CO}_{2}$.

The analysis of the collected source data shows that the average travel time is shorter on non-working days. This may indicate a reduction in transit traffic, especially truck traffic, which has special rules for daily and weekly norms of working time and rest of the driver. This is particularly noticeable in the three time periods 6 a.m. -10 a.m., 6 p.m. -10 p.m. and 10 p.m. -6 a.m. Table 5 shows the fuel consumption and $\mathrm{CO}_{2}$ emissions after passing the transit to the bypass, where the average fuel consumption calculated based on the data from the time periods indicated above was used to calculate the consumption without transit. 
Table 5. Fuel consumption (in litres) and $\mathrm{CO}_{2}$ emissions (in kilograms) without transit

\begin{tabular}{|l|c|c|c|}
\hline \multicolumn{1}{|c|}{ Parameter } & $\begin{array}{c}\text { Unit fuel } \\
\text { consumption }\end{array}$ & $\begin{array}{c}\text { Fuel } \\
\text { consumption* }\end{array}$ & Emission of $\mathrm{CO}_{2}{ }^{*}$ \\
\hline Average consumption Monday-Friday & 0.514 & $6,746.76$ & $15,854.89$ \\
\hline $\begin{array}{l}\text { Average consumption Saturday- } \\
\text { Sunday }\end{array}$ & 0.511 & $6,707.39$ & $15,762.37$ \\
\hline
\end{tabular}

* City traffic at 13,126 vehicles a day

Source: (own elaboration)

Assuming that all transit traffic is transferred to the constructed bypass of Starogard Gdański and there is a reduction in traffic in the town, the total savings for lower fuel consumption and $\mathrm{CO}_{2}$ emissions of vehicles can be calculated (Table 6).

Table 6. Reduction in fuel consumption (litres) and $\mathrm{CO}_{2}$ emissions (kilograms) when directing transit to the bypass

\begin{tabular}{|l|c|c|c|c|}
\hline \multirow{2}{*}{ Parameter } & \multicolumn{2}{|c|}{ Fuel consumption } & \multicolumn{2}{c|}{ Emission of $\mathrm{CO}_{2}$} \\
\cline { 2 - 5 } & Monday-Friday & Saturday-Sunday & Monday-Friday & Saturday-Sunday \\
\hline City traffic currently & 7363.70 & 7061.79 & $17,304.70$ & $16,595.21$ \\
\hline $\begin{array}{l}\text { City traffic without } \\
\text { transit }\end{array}$ & 6746.76 & 6707.39 & $15,854.89$ & $15,762.37$ \\
\hline Savings & $\mathbf{6 1 6 . 9 4}$ & $\mathbf{3 5 4 . 4 0}$ & $\mathbf{1 , 4 4 9 . 8 1}$ & $\mathbf{8 3 2 . 8 4}$ \\
\hline
\end{tabular}

Source: (own elaboration)

Based on the calculations made, we can assume that after moving the transit to the bypass, the road conditions will be close to the optimal ones, which will result in a significant liquefaction of traffic. The resulting savings seem to be significant, especially as the results presented cover a period of 24 hours. By converting these quantities for a month and then a year, we get values that show significant positive effects in the field of environmental protection. It should also be remembered that the results of the experiment were based on data using only a passenger car, and a significant part of the total number of vehicles moving around Starogard Gdański constitute smaller or larger trucks and buses. As a result, the combustion of these vehicles is much larger than a passenger vehicle and consequently, future savings will also be proportionally greater.

\section{Conclusions}

Investments in transport infrastructure are one of the main tools used in the framework of regional development policy. The development of the road network leads to improved accessibility, although different effects may occur in different regions. In economic terms, each of the investments carried out is to lead to a beneficial effect in the form of benefits for the region's economy or the broadly understood social factor. 
One of the key challenges for central and local authorities, including Starogard Gdański, is limiting the issue of congestion. One of the most effective ways of solving such problems is to build city bypasses that would lead to transit traffic outside the city's road network.

The results of the experiment presented in the article confirm the above thesis. Saving time, fuel, reducing $\mathrm{CO}_{2}$ emissions to the atmosphere are specific economic effects that can be achieved by implementing the planned investment in Starogard Gdański. Demonstrating these real savings is an additional argument for entities striving to build the Starogard Gdański bypass.

\section{References}

Alvarez-Ayuso, I., Condeco-Melhorado, A., Gutierrez, J. et al. (2016), Integrating Network Analysis with the Production Function Approach to Study the Spillover Effects of Transport Infrastructure. Regional Studies, 50(6), pp. 996-1015, https://doi.org/10.1080/003434 04.2014.953472.

Alvarez-Ayuso, I., Delgado-Rodriguez, M. (2012), High-capacity Road Networks and Spatial Spillovers in Spanish Regions. Journal of Transport Economics and Policy, 46(2), pp. 281-292.

Aschauer, D. A. (1989), Is public expenditure productive? Journal of Monetary Economics, 23(2), pp. 177-200, https://doi.org/10.1016/0304-3932(89)90047-0.

Banister, D., Berechman, Y. (2001), Transport investment and the promotion of economic growth. Journal of Transport Geography, 9(3), pp. 209-218, https://doi.org/10.1016/S09666923(01)00013-8.

Bąk, M., Ważna, A. (2014), Oszczędność czasu w transporcie pasażerskim w teorii i praktyce, Logistyka, 2, pp. 14-22.

Brocker, J., Rietveld, P. (2009), Infrastructure and regional development. In: Capello, R., Nijkamp, P. (Eds.), Handbook of Regional Growth and Development Theories, Edward Elgar, Cheltenham.

Cantos, P., Gumbau-Albert, M., Maudos, J. (2005), Transport infrastructures, spillover effects and regional growth: evidence of the Spanish case, Journal Transport Reviews, 25(1), pp. 25-50, https://doi.org/10.1080/014416410001676852.

Ciołek, D., Brodzicki, T. (2016), Determinanty produktywności polskich powiatów. Bank i Kredyt, 47(5), pp. 463-494. Available from https://www.researchgate.net/publication/309646152_Determinanty_produktywnosci_polskich_powiatow/download [Accessed 16 March 2019].

Drogi przyjazne środowisku, 2009. Available from https://www.gddkia.gov.pl/dane/gddkia_dps. pdf [Accessed 16 March 2019].

Elshahawany, D. N., Haddad, E. A., Lahr, M. L. (2017), Accessibility, Transportation Cost and Regional Growth: A Case Study for Egypt. Middle East Development Journal, 9(2), pp. 256-277, https://doi.org/10.1080/17938120.2017.1366773.

Gołembska, E. (Ed.) (2010), Kompendium wiedzy o logistyce, Wydawnictwo Naukowe PWN, Warszawa.

Haddad, E. A., Perobelli, F. S., Domingues, E. P. et al. (2011), Assessing the Ex Ante Economic Impacts of Transportation Infrastructure policies in Brazil, Journal of Development Effectiveness, 3(1), pp. 44-61, https://doi.org/10.1080/19439342.2010.545891.

Haddad, E. A., Hewings, G. J. D. (2005), Market Imperfections in a Spatial Economy: Some Experimental Results, The Quarterly Review Economics and Finance, 45(2-3), pp. 476-496, https://doi.org/10.1016/j.qref.2004.12.016. 
Islam, S. (2003), Distance Decay in Employment and Spatial Spillovers of Highways in Appalachia. Research Paper, Department of Economics and Regional Research Institute, West Virginia University.

Kaczyńska, W., Korycińska, K. (2014), Wpływ infrastruktury transportu drogowego na rozwój regionu. Zeszyty Naukowe Uniwersytetu Przyrodniczo-Humanistycznego w Siedlcach, Administracja i Zarządzanie, 103, pp. 319-324.

Karlsson, C., Gråsjö, U., Andersson, M. (2006), Regional Knowledge Accessibility and Regional Economic Growth, Working Paper Series in Economics and Institutions of Innovation 66, Royal Institute of Technology, CESIS - Centre of Excellence for Science and Innovation Studies. Available from https://core.ac.uk/download/pdf/7036388.pdf [Accessed 1 March 2019].

Komornicki, T., Rosik, P., Śleszyński, P. et al. (2013), Wpływ budowy autostrad i dróg ekspresowych na rozwój społeczno-gospodarczy i terytorialny Polski, Ministerstwo Rozwoju Regionalnego, Warszawa.

Koźlak, A. (2008), Ekonomika transportu, Teoria i praktyka gospodarcza, Gdańsk.

Lakshmanan, T. (2011), The broader economic consequences of transport infrastructure investments. Journal Transport of Geographic, 19(1), pp. 1-12, https://doi.org/10.1016/j. jtrangeo.2010.01.001.

Lein, J., Day, K. (2008), Assessing the growth-inducing impact of the Appalachian Development Highway System in southern Ohio: did policy promote change? Land Use Policy, 25(4), pp. 523-532, https://doi.org/10.1016/j.landusepol.2007.11.006.

Levkovich, O., Rouwendal, J., van Marwijk, R. (2016), The effects of highway development on housing prices. Transportation, 43(2), pp. 379-405. Available from https://link.springer. com/article/10.1007/s11116-015-9580-7/ [Accessed 19 March 2019].

Linneker, B., Spence, N. (1996), Road transport infrastructure and regional economic development. The regional development effects of the M25 London orbital motorway, Journal Transport of Geographic, 4(2), pp. 77-92, https://doi.org/10.1016/0966-6923(96)00001-4.

Neider, J. (2008), Transport międzynarodowy, Polskie Wydawnictwo Ekonomiczne, Warszawa.

Piskozub, A. (1982), Gospodarowanie w transporcie. Podstawy teoretyczne, Wydawnictwa Komunikacji i Łączności, Warszawa.

Program Budowy Dróg Krajowych na lata 2014-2023 z perspektywa do 2025 r. (2015), Ministerstwo Infrastruktury, Warszawa.

PwC (2013), Budowa dróg w Polsce, Raport na zlecenie GDDKiA. Available from https://www. pwc.pl/pl/publikacje/assets/budow_drog_w_polsce_raport_pwc.pdf [Accessed 9 March 2019].

Ribeiro, A., Antunes, A., Paez, A. (2010), Road accessibility and cohesion in lagging regions: Empirical evidence from Portugal based on spatial econometric models, Journal Transport of Geography, 18(1), pp. 125-132, https://doi.org/10.1016/j.jtrangeo.2009.03.002.

Rietveld, P. (1994), Spatial economic impacts of transport infrastructure supply, Transportation Research Part A: Policy and Practice, 28(4), pp. 329-341, https://doi.org/10.1016/09658564(94)90007-8.

Rolbiecki, R., Wojewódzka-Król, K. (2013), Wykorzystanie funduszy unijnych w rozwoju transportu w Polsce. In: Rolbiecki, R. (Ed.), Aktualne problemy rozwoju transportu i logistyki, Zeszyty Naukowe Uniwersytetu Gdańskiego. Ekonomika Transportu i Logistyka, 47 , pp. 37-46.

Sakamoto, H. (2012), CGE Analysis of Transportation cost and Regional Economy: East Asia and Northern Kyushu, Regional Science Inquiry Journal, 4(1), pp. 121-140.

Szafranko, E. (2014), Metody analizy wariantów inwestycji drogowych, Drogownictwo, 1, pp. 18-25.

Transprojekt Gdańsk Sp. z o.o. (2015), Studium korytarzowe oraz studium techniczno-ekonomiczno-środowiskowe wraz z materiatami do decyzji o środowiskowych uwarunkowaniach 
dla budowy Obwodnicy Starogardu Gdańskiego na parametrach drogi Gp, Tom IX - część ekonomiczna.

U S Energy Information Administration (2017), How much carbon dioxide is produced from U.S. gasoline and diesel fuel consumption? Available from https://www.eia.gov/tools/faqs/faq. php?id=307\&t=11 [Accessed 10 March 2019].

Urbanyi-Popiołek, I. (2013), Ekonomiczne i organizacyjne aspekty transportu, Bydgoszcz, Wyższa Szkoła Gospodarki w Bydgoszczy.

Venables, A. J. (2007), Evaluating Urban Transport Improvements: Cost-Benefit Analysis in the Presence of Agglomeration and Income Taxation, Journal of Transport Economics and Policy, 41(2), pp. 173-188.

Vickerman, R. (2008), Transit investment and economic development, Research in Transportation Economics, 23(1), pp. 107-115, https://doi.org/10.1016/j.retrec.2008.10.007.

Vickerman, R., Spiekermann, K., Wegener, M. (1999), Accessibility and Economic Development in Europe, Regional Studies, 33(1), pp. 1-15, https://doi.org/10.1080/003434 09950118878.

\section{Corresponding author}

Marek Gierszewski can be contacted at: marek_301@wp.pl 